\title{
The role of phytophysiognomies and seasonality on the structure of ground-dwelling anuran (Amphibia) in the Pampa biome, southern Brazil
}

\author{
FRANCIÉLE P. MARAGNO ${ }^{1}$, TIAGO G. SANTOS ${ }^{2}$ and SONIA Z. CECHIN ${ }^{3}$ \\ ${ }^{1}$ Programa de Pós-Graduação em Biodiversidade Animal, \\ Universidade Federal de Santa Maria, 97105-900 Santa Maria, RS, Brasil \\ ${ }^{2}$ Universidade Federal do Pampa, Campus São Gabriel, 97300-000 São Gabriel, RS, Brasil \\ ${ }^{3}$ Departamento de Biologia, Programa de Pós-Graduação em Biodiversidade Animal, \\ Universidade Federal de Santa Maria, 97105-900 Santa Maria, RS, Brasil \\ Manuscript received on January 18, 2012; accepted for publication on December 6, 2012
}

\begin{abstract}
Considering that habitat use by amphibians is related both with climate and environmental features, we tested the hypothesis that anuran assemblages found in different phytophysiognomies and in different seasons vary in structure. Additionally, we searched for species which can be indicators of habitat and seasons. The study was conducted in the Pampa biome, southern Brazil. Sampling was done through pitfall traps placed in three phytophysiognomies: grassland, ecotone grassland/forest; and forest. The seasonality factor was created by grouping months in warn and cold seasons. Sixteen species were found and the assemblages were influenced both by phytophysiognomies and climatic seasonality. In a paired comparison, the three phytophysiognomies differed in structure of assemblage from each other. Physalaemus henselii, P. riograndensis, Pseudopaludicola falcipes and Pseudis minuta were indicators of ecotone. Leptodactylus gracilis and Physalaemus biligonigerus were indicators of grassland. None species was indicator of forest. Most of the species were indicators of warm season: Elachistocleis bicolor, Leptodactylus fuscus, L. gracilis, L. latinasus, L. latrans, L. mystacinus, Physalaemus biligonigerus, P. cuvieri and Pseudis minuta. None species was indicator of cold season. We found that even for species of open areas, as Pampa, heterogeneous phytophysiognomies are important for maintaining abundance and constancy of populations of anuran.
\end{abstract}

Key words: amphibian, community, ecotone, pitfalls traps, seasons.

\section{INTRODUCTION}

The factors influencing organization of anuran assemblage are related with availability, sharing and partitioning of resources like prey, shelter against predators, vocalization and egg deposition sites, maintaining of body temperature and moisture, interactions with other species, and historical constraints (Lillywhite et al. 1973, Toft 1985,

Correspondence to: Franciéle Pereira Maragno

E-mail: fmaragno@gmail.com
Barbault 1991, Wellborn et al. 1996, Lima et al. 2000, Wente and Philips 2005, Prado et al. 2005, Tomé et al. 2010). From the association of all these factors some patterns can emerge.

The temporal pattern of activity of amphibians is highly influenced by climatic conditions, mainly due to their reproductive characteristics. In this sense, the constancy and intensity of precipitation throughout the year are related to a continuous reproductive activity, as in tropical forests, or to 
a seasonal reproductive activity, as in regions with markedly dry and rainy seasons (Gottsberger and Gruber 2004, Prado et al. 2005, Vasconcelos and Rossa-Feres 2005, Bernarde 2007). A seasonal reproductive pattern also occurs where temperature and photoperiod are seasonal, but rainfall is constant, as in subtropical climate (Sanchez et al. 2007, Both et al. 2008, Canavero et al. 2009, Canavero and Arim 2009). In this sense, an increase in the activity of anurans is expected during the breeding season, mainly associated with higher rates of movements in search of breeding sites and recruitment of juveniles.

On a local scale, environmental features such as microclimate provided by vegetation, density of bushes, density of canopy cover, and depth of leaflitter are some of the important issues regulating amphibian assemblages in forests (Krishnamurthy 2003, Paris 2004, Van Sluys et al. 2007). In areas of open vegetation, the presence and abundance of a species may be associated with availability of favorable sites for reproduction, as well as the structural features of the reproductive sites (Prado et al. 2005, Vasconcelos et al. 2009, Silva and Rossa-Feres 2011, Silva et al. 2012). A distinct pattern is found in the ecotones, where there are resources belonging to both types of vegetation, with greater environmental complexity and richness of organisms (Ries et al. 2004). Moreover, according to the intermediate disturbance hypothesis (Connel 1978), landscape changes in intermediary intensity and frequency, as observed in ecotones, produce a greater diversity of organisms as there is a constant turnover of species in these regions. Temperature, density of shrubs, canopy and leaf-litter cover, and parasites have been related to composition of herpetofauna and distance from the edge (Schlaepfer and Gavin 2001, Urbina-Cardona et al. 2006). Differences between a gradient from open to forestall phytophysiognomies have being portrayed in studies concerning habitat fragmentation (Ries et al. 2004, Urbina-Cardona et al. 2006, Vasconcelos et al. 2010). However, few studies discuss habitat use in natural mosaics of vegetation (e.g. Julião et al. 2004).
The Pampa biome is composed by natural grasslands that cover south of Brazil, Uruguay and central region of Argentina. The typical ecosystem on the south of Brazil is a natural mosaic of Seasonal Forests from Atlantic Domain and grassland (IBGE 2004, Oliveira-Filho et al. 2006). Currently, 50\% of the natural vegetation of Brazilian Pampa was converted in pastures, crops and forestry (Cordeiro and Hasenack 2009, Santos and Trevisan 2009). Indeed, although several regions of Brazilian Pampa are listed as priorities for biodiversity conservation, only $2.58 \%$ are designed to conservation units (Brandão et al. 2007).

In southern Brazil, studies that address the range of amphibian assemblages along environmental and seasonal gradients are recent (e.g. Moreira et al. 2007, Both et al. 2008, Santos et al. 2008, Moreira et al. 2010). Such studies were developed manly at breeding sites and did not evaluate the habitat use as a whole. Studies beyond breeding sites identify the relationship of species and the matrix surrounding these reproductive places, complementing the knowledge generated from studies in breeding sites. As habitat use by amphibians is related both with climate and environmental features, we tested the hypothesis that anuran assemblages found in different phytophysiognomies and in different seasons vary in structure. Moreover, considering that the species requirements (e.g. feeding, reproductions and thermic shelter) may vary according to seasonal climatic changes and that phytophysiognomies may vary on the availability of resources according to its characteristics (e.g. heterogeneity), we also test an integrated effect of the factors "habitat" and "season". Additionally, we searched for species which can be indicators of habitat and seasons.

\section{MATERIALS AND METHODS}

The study was conducted in Santa Maria, central portion of Rio Grande do Sul, southern Brazil. The region belongs to Pampa biome (IBGE 2004), 
near the southern boundary of the Semideciduous Forest. The climate is subtropical humid (STUM), with annual precipitation of $1,708 \mathrm{~mm}$ and no dry season (Maluf 2000). The climate is characterized by seasonal variation of photoperiod and temperature, varying from zero or few negatives in the winter to $40^{\circ} \mathrm{C}$ in the summer, with the average annual temperature of $19.2^{\circ} \mathrm{C}$ (Pereira et al. 1989). The photoperiod varies from 10 (May-August) to 14 hours (December-January) along the year (Observatório Nacional Brasileiro 2012).

The sample site is located at Campo de Instrução do Exército de Santa Maria (Army Field Instruction, CISM), (2943'44'S and 5342'44'W; Figure 1). The CISM has an area of 5,786 ha, of which about $30 \%$ are composed of clumps of native forest and riparian vegetation, with the remainder covered by native grassland partially intended for livestock. Sampling was performed using pitfall traps with drift fences (Cechin and Martins 2000). Pitfalls were placed in three distinct phytophysiognomies: 1) grassland; 2) ecotone grassland/forest; and 3) forest. In each phytophysiognomie we placed ten barrels of 2001 in line, spaced $15 \mathrm{~m}$ apart and connected by fences of 1 $\mathrm{m}$ high. The line of traps in the grassland was spaced $2 \mathrm{~km}$ apart from the line of traps in the ecotone and $4 \mathrm{~km}$ from the traps in the forest. In the ecotone, the line of traps was placed exactly at the edge between the grassland and a fragment of riparian forest. The traps in the forest were placed in the interior of the fragment and approximately $1 \mathrm{~km}$ from the forest edge (Figure 1). The traps were open continuously from January 1996 to March 1998, totalizing 27 months of sampling, and they were reviewed every two days. All individuals were collected and deposited at the "Coleção de Herpetologia da Universidade Federal de Santa Maria" (ZUFSM). For analysis, we included only species with total abundance greater than 10 individuals considering all sampling sites and time to avoid punctual occurrences.

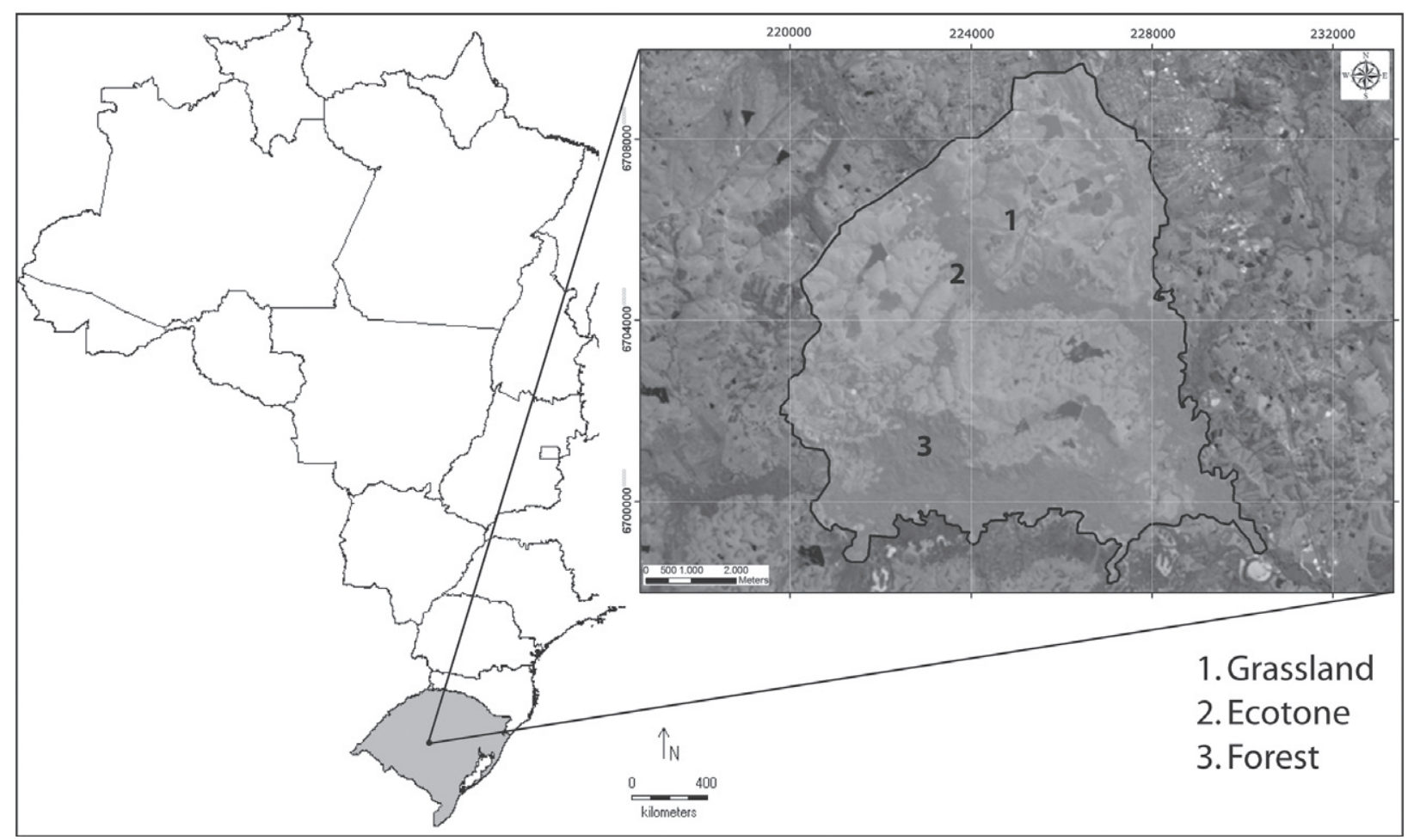

Figure 1 - Study site localization. Army Field Instructions of Santa Maria, Rio Grande do Sul, Brazil. Numbers indicate the position of the lines of pitfall traps in the three phytophysiognomies (grassland, ecotone, and forest) to sampling of anurans. 
To investigate the variation in the structure of assemblage (in the sense of composition and abundance simultaneously) between the phytophysiognomies and between the seasons we used a PERMANOVA for repeating measures (Anderson et al. 2008), considering two factors: i) phytophysiognomies (grassland, ecotone, and forest) and ii) seasonality (spring/summer and autumn/winter). To compose the seasonality factor, months were grouped in two seasons (warm and cold) since the higher activity of anurans in the southern Brazil occurs during hotter and longer photoperiods (Both et al. 2008, Santos et al. 2008).

The PERMANOVA allows to explore the effect of each factor individually (phytophysiognomies and seasonality), as well as the interaction between factors. The modality "repeated measures" was developed to deal with sampling designs containing measures repeated in time (temporal pseudo-replication). The PERMANOVA was based at the indices of binomial dissimilarity deviation (Clark and Gorley 2006), using species abundance transformed by square root and 999 permutations. Additionally, the dissimilarity matrix was represented by a Non- Metric Multidimensional Scaling (NMDS) to exhibit the dispersion of samples (months) on the two factors analyzed (phytophysiognomies and seasonality). Information loss during the ordination was measured by stress (S) according to Clark and Warwick (2001). Analyses were conduct on package PERMANOVA+ add on 1.01 (Anderson et al. 2008), available in PRIMER-E 6.1.11 (Clarke and Gorley 2006).

Previous to PERMANOVA, the homogeneity of variance (sphericity) of samples was tested through Levene's test. When the test is significant, the homogeneity must be rejected. Variances were homogeneous for samples from the three phytophysiognomies $(\mathrm{F}=2.77 ; \mathrm{p}>0.05)$.

Additionally, we used an Indicator Species Analysis (ISA) (Dufrêne and Legendre 1997) to identify the species that contributed most to the segregation between the three phytophysiognomies and two seasons. In this analysis, we define groups a priori and test which species represent the groups. For this, each species gain an indicator value (IV) for each group. This value range from zero (none indication) to 100 (perfect indication) and is calculated based on species abundance and frequency in the sampling unities (phytophysiognomies and seasons). Therefore, a good indicative species must be frequent and abundant in the samples of its group (Dufrêne and Legendre 1997). The null hypothesis of this analysis considers the maximum indicator value is not greater than expected by chance. The significance of groups IV was tested through Monte Carlo permutation (5000).

\section{RESULTS}

We found 16 species of ground-dwelling anuran, belonging to six families. Species richness varied from 13 to 15 in the phytophysiognomies (Figure 2). The greater number of individuals was found

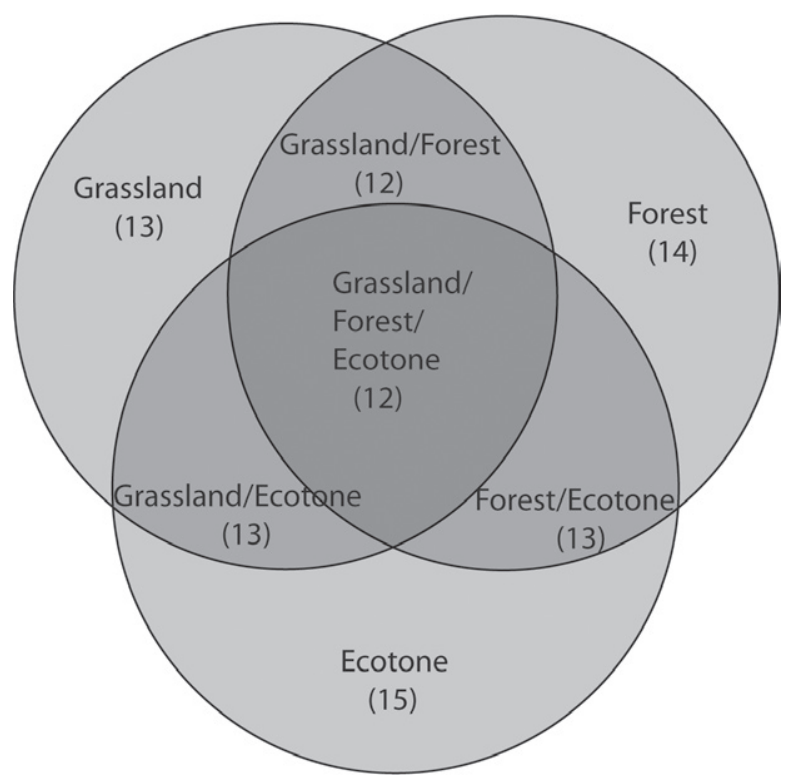

Figure 2 - Venn's diagram representing the richness of ground-dwelling anurans in three phytophysiognomies (grassland, ecotone, and forest), and richness shared among phytophysiognomies in an assemblage of Pampa biome, Brazil, from January 1996 to March 1998. 
in the ecotone grassland/forest (62.8\%), followed by grassland (23.4\%) and forest (13.8\%). In overall, Pseudopaludicola falcipes, Leptodactylus latrans and Physalaemus cuvieri were the most abundant. Three species were rare at study site: Leptodactylus chaquensis, Rhinella achavali and $R$. henselli (Table I). Physalaemus cuvieri (66.7\%), P. biligonigerus (59\%) and Leptodactylus gracilis $(59 \%)$ were the most frequent species of grassland. In the forest, Physalaemus cuvieri (59\%), Leptodactylus latrans (55.5\%) and L. fuscus (37\%) were the most frequent; while in the ecotone, the most frequent were Physalaemus cuvieri (81.5\%), P. riograndensis $(77.8 \%)$ and Pseudopaludicola falcipes (74\%) (Table I).

The anuran assemblage was significantly influenced by phytophysiognomies and seasons individually (Pseudo-F $=25.83, \mathrm{p}<0.01$; Pseudo-F $=31.74, \mathrm{p}<0.01$, respectively). The interaction between these two factors did not affect the assemblage (Pseudo-F $=1.08$ and $\mathrm{p}=0.39$ ). In a paired comparison, we found that the three phytophysiognomies differ in structure of assemblage from each other $(\mathrm{T}=3.56$ and $\mathrm{p}<0.01$

TABLE I

Abundance of ground-dwelling anurans in three phytophysiognomies (grassland, ecotone, and forest) and two seasons (warm and cold) of Pampa biome, Brazil, from January 1996 to March 1998. \%O = Percentage of Occurrence (percentage of months in which a species was found in relation to total months of the study (27).

\begin{tabular}{|c|c|c|c|c|c|c|c|c|c|c|}
\hline \multirow{2}{*}{ Species } & \multicolumn{5}{|c|}{ Phytophysiognomies } & \multicolumn{5}{|c|}{ Seasons } \\
\hline & Grassland & $\% \mathrm{O}$ & Forest & $\% \mathrm{O}$ & Ecotone & $\% \mathrm{O}$ & Warm & $\% \mathrm{O}$ & Cold & $\% \mathrm{O}$ \\
\hline \multicolumn{11}{|l|}{ Bufonidae } \\
\hline Rhinella achavali & 1 & 3.7 & 0 & 0 & 1 & 3.7 & 2 & 13 & 0 & 0 \\
\hline Rhinella henselli & 0 & 0 & 5 & 18 & 0 & 0 & 1 & 6.7 & 4 & 17 \\
\hline \multicolumn{11}{|l|}{ Cycloramphidae } \\
\hline Odontophrynus americanus & 6 & 18 & 3 & 11 & 4 & 15 & 5 & 27 & 8 & 42 \\
\hline \multicolumn{11}{|l|}{ Hylidae } \\
\hline Pseudis minuta & 1 & 3.7 & 9 & 18 & 145 & 52 & 148 & 87 & 8 & 33 \\
\hline \multicolumn{11}{|l|}{ Leiuperidae } \\
\hline Physalaemus biligonigerus & 82 & 59 & 3 & 11 & 10 & 19 & 82 & 80 & 13 & 50 \\
\hline Physalaemus cuvieri & 102 & 67 & 164 & 59 & 220 & 81 & 400 & 100 & 86 & 75 \\
\hline Physalaemus henselii & 0 & 0 & 0 & 0 & 32 & 48 & 22 & 60 & 10 & 33 \\
\hline Physalaemus riograndensis & 29 & 3.7 & 1 & 3.7 & 158 & 78 & 157 & 80 & 31 & 75 \\
\hline Pseudopaludicola falcipes & 11 & 26 & 18 & 33 & 259 & 74 & 196 & 87 & 92 & 75 \\
\hline \multicolumn{11}{|l|}{ Leptodactylidae } \\
\hline Leptodactylus chaquensis & 0 & 0 & 1 & 3.7 & 1 & 3.7 & 0 & 0 & 2 & 17 \\
\hline Leptodactylus fuscus & 109 & 41 & 40 & 37 & 95 & 63 & 232 & 87 & 12 & 33 \\
\hline Leptodactylus gracilis & 72 & 59 & 1 & 3.7 & 22 & 48 & 83 & 87 & 12 & 42 \\
\hline Leptodactylus latinasus & 2 & 3.7 & 3 & 11 & 7 & 22 & 12 & 53 & 0 & 0 \\
\hline Leptodactylus latrans & 34 & 48 & 26 & 55 & 225 & 55 & 248 & 87 & 37 & 50 \\
\hline Leptodactylus mystacinus & 10 & 18 & 3 & 11 & 24 & 30 & 28 & 53 & 6 & 25 \\
\hline \multicolumn{11}{|l|}{ Microhylidae } \\
\hline Elachistocleis bicolor & 19 & 59 & 7 & 0.19 & 85 & 48 & 103 & 87 & 8 & 50 \\
\hline Total abundance & 479 & & 283 & & 1287 & & 1720 & & 327 & \\
\hline Richness & 13 & & 14 & & 15 & & 15 & & 14 & \\
\hline
\end{tabular}


(comparing grassland with forest); $\mathrm{T}=5.33$ and $\mathrm{p}$ $<0.01$ (comparing grassland with ecotone); $\mathrm{T}=$ 5.56 and $\mathrm{p}<0.01$ (comparing forest with ecotone). The greatest dissimilarity was among samples from ecotone, while the lowest dissimilarity was among samples from the forest. In addition, grassland and ecotone were the most dissimilar to each other, while grassland and forest were the least dissimilar (Figure 3; Table II).
According to the Indicator Species Analysis (ISA), six species ( $46 \%$ of total) had occurrence and abundance significantly further than expected by chance in some of the phytophysiognomies (p $<0.05)$. Physalaemus henselii, P. riograndensis, Pseudopaludicola falcipes and Pseudis minuta were indicative of ecotone. Two species were indicative of grassland: Leptodactylus gracilis and Physalaemus biligonigerus. None species

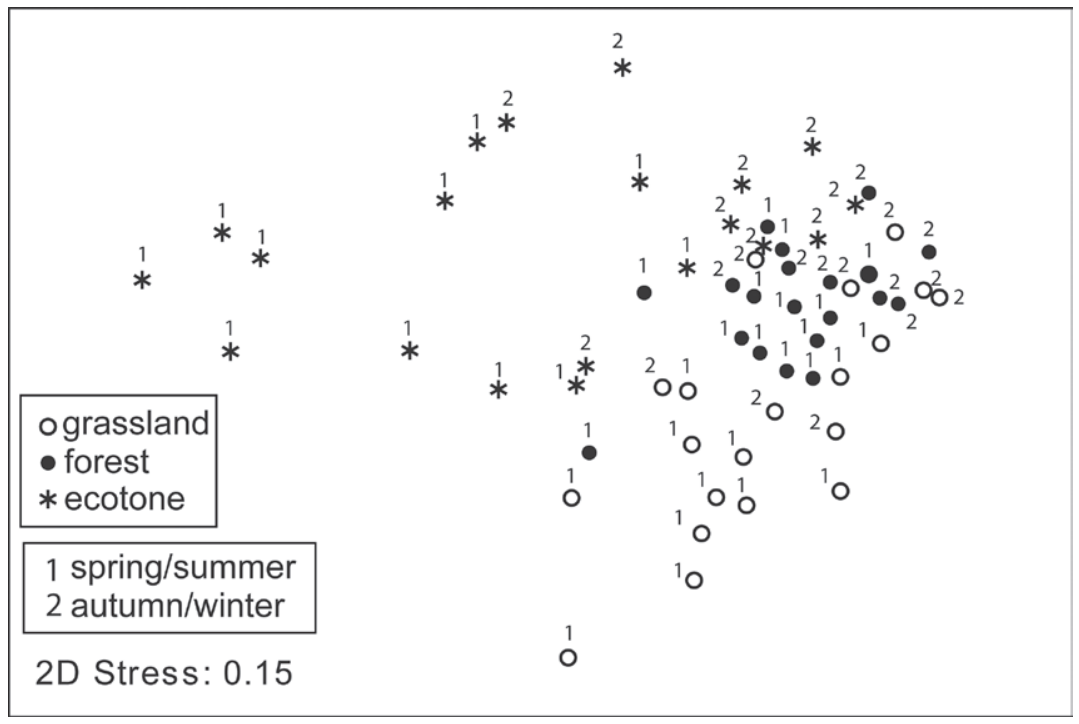

Figure 3 - Non -Metric Multidimensional Scaling (NMDS) representing the dispersion of samples in relation to two factors: phytophysiognomies (grassland, ecotone, and forest) and seasons (warm and cold) for an assemblage of ground-dwelling anurans of Pampa biome, Brazil, from January 1996 to March 1998.

TABLE II

Average dissimilarity between and within the factor phytophysiognomies (grassland, ecotone, and forest) for an assemblage of ground-dwelling anuran of Pampa biome, Brazil, from January 1996 to March 1998.

\begin{tabular}{cccc}
\hline & Grassland & Forest & Ecotone \\
\hline Grassland & 5.89 & - & - \\
Forest & 6.27 & 4.01 & - \\
Ecotone & 10.48 & 9.54 & 8.97 \\
\hline
\end{tabular}

was indicative of forest (Table III). Regarding seasonality, nine species $(56 \%$ of total) were indicative of warm season: Elachistocleis bicolor, Leptodactylus fuscus, L. gracilis, L. latinasus, L. latrans, L. mystacinus, Physalaemus biligonigerus, P. cuvieri and Pseudis minuta. None species was indicative of cold season (Table IV).

\section{DISCUSSION}

Phytophysiognomies influenced the grounddwelling anuran so that each vegetation type had distinct structure of assemblage. It is known that characteristic of habitat can influence the presence of amphibians at the environment. In fact, studies of Neotropical amphibian assemblage observed a distinct structure than expected by chance, for both adults and tadpoles (Vasconcelos et al. 2009, Both et al. 2011, Moreira and Maltichik 2012). 
TABLE III

Indicator value (IV) resulting from an Indicator Species Analysis (ISA) for an assemblage of ground-dwelling anuran in three phytophysiognomies (grassland, ecotone, and forest) in the Pampa biome, Brazil, from January 1996 to March 1998. * for $\mathbf{p} \leq \mathbf{0 . 0 5}$ and $* * *$ for $\mathbf{p} \leq \mathbf{0 . 0 0 1}$.

\begin{tabular}{ccc}
\hline Species & Phytophysiognomies & IV \\
\hline P. falcipes & Ecotone & $90.6^{* * *}$ \\
P. riograndensis & Ecotone & $75.8^{* * *}$ \\
P. biligonigerus & Grassland & $66.2^{* * *}$ \\
P. henselii & Ecotone & $65^{* * *}$ \\
L. gracilis & Grassland & $61.1^{* * *}$ \\
P. minutus & Ecotone & $51.6^{* * *}$ \\
L. latrans & Ecotone & 43.6 \\
E. bicolor & Ecotone & $42.2^{*}$ \\
P. cuvieri & Ecotone & 37.3 \\
L. fuscus & Ecotone & 27.4 \\
L. latinasus & Ecotone & 18.1 \\
L. mistacinus & Ecotone & 16 \\
O. americanus & Grassland & 10.9 \\
\hline
\end{tabular}

TABLE IV

Indicator value (IV) resulting from an Indicator Species Analysis (ISA) for an assemblage of ground-dwelling anuran during two seasons (warm and cold) in the Pampa biome, Brazil, from January 1996 to March 1998. * for $\mathbf{p} \leq \mathbf{0 . 0 5}, * *$ for $\mathbf{p} \leq \mathbf{0 . 0 1}$, and $* * *$ for $\mathbf{p} \leq \mathbf{0 . 0 0 1}$.

\begin{tabular}{ccc}
\hline Species & Seasons & IV \\
\hline P. cuvieri & Warm & $81.1^{* * *}$ \\
L. fuscus & Warm & $75^{* * *}$ \\
L. latrans & Warm & $67.6^{* * *}$ \\
L. gracilis & Warm & $51^{* * *}$ \\
E. bicolor & Warm & $49.3^{* *}$ \\
P. biligonigerus & Warm & $40.5^{*}$ \\
P. riograndensis & Warm & 39.9 \\
P. falcipes & Warm & 37.6 \\
P. minutus & Warm & $34.7^{*}$ \\
L. latinasus & Warm & $28.6^{* *}$ \\
L. mistacinus & Warm & $28.2^{*}$ \\
O. americanus & Cold & 16.7 \\
P. henselii & Warm & 16.4 \\
\hline
\end{tabular}

In this study, the differences in structure of assemblage were mainly due variation in abundance and frequency of occurrence of each species in each phytophysiognomie, since the composition of species was similar between phytophysiognomies (see Table I). In the grassland, the greatest abundance and frequency of occurrence of some species, mainly Leptodactylus fuscus, L. gracilis and Physalaemus biligonigerus, distinguished the assemblage structure from the other phytophysiognomies. In fact, this two last species were indicator of grassland. These species are considered abundant along their geographic distribution and are very plastic in habitat use: being found in grasslands, wetland, dunes, forest, growing areas of soybean and rice, and urban areas (Peltzer et al. 2003, Attademo et al. 2005, Loebmann and Vieira 2005, Lucas and Fortes 2008, Santos et al. 2008). Leptodactylus gracilis belongs to Leptodactyus fuscus group, whose species deposit eggs in cavities in the ground that are flooded, releasing the tadpoles to complete their development in ponds closer (Heyer 1978). This reproductive mode confers higher protection against dehydration and predation, and possibilities to a great versatility in habitat use. Physalaemus biligonigerus is able of reproducing both in ponds within agricultural lands and in areas of pristine vegetation (Peltzer et al. 2006), using shallow, temporary ponds, and semi-covered by grasses and sedges (Zarancho et al. 2004). Thus, these species present a set of characteristics which allow them to successfully use open areas.

Grassland is the reproductive habitat of pampean species and a high abundance and frequency of occurrence would be expected in this phytophysiognomy (Cei 1980, Manzano et al. 2004, Núñez et al. 2004, Both et al. 2008, Santos et al. 2008). However, some species were more abundant in other phytophysiognomies. Open areas are environments of large variation in climatic conditions (Inger and Colwell 1977, Silvano et al. 2003, Urbina-Cardona et al. 2006) and it is possible that species less tolerant to these variations search for shelter in phytophysiognomies as forests or ecotone, returning to the grassland only for breeding.

In the forest occurred the lowest anuran 
abundance, with dominance of Physalaemus cuvieri. Furthermore, most species found in the forest had low frequency throughout the study, as well as anuran samples of this vegetation type were the most similar to each other, revealing great homogeneity. In forests, the richness and composition of vegetation, elevation, structure and depth of leaf-litter, and proximity to ponds are some factors that may influence richness, abundance, and composition of anuran assemblages (Paris and McCarthy 1999, Willians and Hero 2001, Peltzer et al. 2003, Van Sluys et al. 2007). However, in the present study, the structure found in the forest seems to be a consequence of an opportunist occurrence to foraging and maintenance of temperature and body moisture, as observed for anurans in fragments of Semideciduous Forest (Silva and Rossa-Feres 2007).

In a community, species may be affected in a lesser or greater degree by the environment, depending on how they use this environment (Urbina-Cardona et al. 2006). Anurans of Pampa use mainly lentic ponds localized in grassland or associated with wet lands as reproduction sites (Both et al. 2008, Santos et al. 2008). In the present study, there were no lentic ponds in the forest and the sampling method excludes species that uses the vertical stratification of vegetation. These two cues may explain the absence of indicator species in this phytophysiognomie.

The structure of the ground-dwelling anuran assemblage in the ecotone was distinct from the two others phytophysiognomies and most species (56\%) were found in $48 \%$ or more of the months during the study. In addition, anuran samples from ecotone were the least similar to each other, demonstrating the heterogeneity of samples. In this study, the ecotone emerges from the natural proximity of grassland and riparian forest. Considering the high ecological flow, the access to resources from two distinct phytophysiognomies, and the ecological interactions in the ecotones, it is expected that communities in ecotones differs from those which created them (Ries et al. 2004). In this study, the assemblages from the grassland and from the forest are more similar to each other than the samples from ecotone among themselves. This reinforces the idea of heterogeneity of communities in transition areas (Connel 1978). For the same study site, highest richness of snakes was also found in ecotone (S.Z. Cechin, unpublished data).

Environmental characteristics may cause a differential effect in each population (Schlaepfer and Gavin 2001, Willian and Hero 2001, Pineda and Halffter 2004) and in this study, Physalaemus henselii, P. riograndensis, Pseudopaludicola falcipes and Pseudis minuta were associated to the ecotone. This is a consequence of a high abundance and frequency of these species in this phytophysiognomie along the months, with $P$. henselii found only in the ecotone. All these species may be found in open and disturbed habitats (Peltzer et al. 2003, Attademo et al. 2005, Peltzer et al. 2006, Santos et al. 2008). However, some studies which evaluated their reproductive sites occupancy recorded them in ponds close to forest areas or inside no disturbed riparian forest (Peltzer et al. 2003, 2006). In this study, the riparian forest was periodically waterlogged providing a moister substrate that amphibians may use as shelter against dehydration, especially small species such as Physalaemus riograndensis and Pseudopaludicola falcipes. In addition, forests edges may concentrate a high number of insects (Antonini et al. 2003) that are important food resources for amphibians, and they also offer a variety of shelters against predation created by the heterogeneity of the vegetation. Thus, it is possible that species indicators of ecotone are more sensitive to the availability of all this resources. Leptodactylus fuscus, L. latrans and Physalaemus cuvieri also occurred in high frequency and abundance in the ecotone, but these species were not identified as indicator of this phytophysiognomy because they were also abundant and frequent in the others two phytophysiognomies.

The structure of the assemblage had a seasonal pattern, with the most of the species indicators of 
warm season. This result can be understood as an overall pattern of activity of the assemblage. The association between the annual cycle of activity of amphibians with climatic factors have been widely reported (e.g. Gottsberger and Gruber 2004, Bernarde 2007, Canelas and Bertoluci 2007, Sanchez et al. 2007). In subtropical temperate regions, temperature and photoperiod are considered the most important factors on the regulation of reproductive activity of anurans (Both et al. 2008, Canavero and Arim 2009), which is more intense in warmer and with longer photoperiod months (Both et al. 2008, Santos et al. 2008). A higher frequency of capture in the warm season was then expected since the most species of amphibians are in reproductive activity during this period in the southern Brazil (Both et al. 2008, Santos et al. 2008).

From conservation point of view, removal of native vegetation with consequent emergence of an edge affects negatively species with restrict requirements and that tolerate little variation in environmental conditions (Silvano et al. 2003). However, Pampa is a very complex biome naturally composed by native mosaics of grassland and forests (Boldrini 2009) and whose resulting ecotones are keys to ensure the diversity of species, serving as shelter, feeding areas and corridors (Bencke 2009). The present study reinforces the importance of theses natural mosaics and ecotones of Pampa since we demonstrated that each phytophysiognomie was responsible for the maintenance of distinct assemblage of ground-dwelling anuran. In this sense, the increase of removal of riparian forest, patches of forest, and wetlands stimulated by the changes proposed by the new Brazilian Forest Code may have a negative impact also on the amphibian fauna.

\section{ACKNOWLEDGMENTS}

We are grateful to CISM for allowing access to the study site. We also thank Cynthia P.A. Prado, Elaine Lucas, Nilton Caceres and Vanessa Fortes for suggestions made on the manuscript. FPM is grate- ful to Coordenação de Aperfeiçoamento de Pessoal de Nível Superior (CAPES) for the doctorate's degree fellowships granted, and SZC is grateful to Conselho Nacional de Desenvolvimento Científico e Tecnológico (CNPq) for a research fellowship (Process No. 303359/2009-9).

\section{RESUMO}

Considerando que o uso do habitat pelos anfíbios está relacionado tanto com clima quanto com características ambientais, testamos as hipóteses de que taxocenoses de anuros encontradas em diferentes fitofisionomias e estações diferem em estrutura. Adicionalmente, buscamos espécies que podem ser indicadoras de habitat e estações. O estudo foi desenvolvido no bioma Pampa, sul do Brasil. A amostragem foi realizada através de armadilhas de interceptação e queda instaladas em três fitofisionomias: campo, ecótono campo/mata e mata. O fator sazonalidade climática foi criado agrupando os meses em estações quente e fria. Dezesseis espécies foram encontradas e as taxocenoses foram influenciadas pelas fitofisionomias e sazonalidade climática. Em uma comparação pareada, as três fitofisionomias diferiram entre si em estrutura da taxocenose. Physalaemus henselii, P. riograndensis, Pseudopaludicola falcipes e Pseudis minuta foram indicadoras de ecótono. Leptodactylus gracilis e Physalaemus biligonigerus foram indicadoras de campo. Nenhuma espécie foi indicadora de mata. A maioria das espécies foi indicadora da estação quente: Elachistocleis bicolor, Leptodactylus fuscus, L. gracilis, L. latinasus, L. latrans, L. mystacinus, Physalaemus biligonigerus, P. cuvieri e Pseudis minuta. Nenhuma espécie foi indicadora da estação fria. Observamos que mesmo para espécies de áreas abertas, como o Pampa, fitofisionomias heterogêneas são importantes para manutenção da abundância e constância das populações de anuros.

Palavras-chave: anfíbios, comunidade, ecótono, armadilhas pitfalls, estações.

\section{REFERENCES}

ANDERSON MS, GORLEY RN AND ClARKe KR. 2008. Permanova+ for PRIMER: guide to software and statistical methods. Primer-E: Plymouth, 214 p. 
ANTONINI Y, ACCACIO GM, CABRAL BC, FonTENELLE JCR, NASCIMENTO MT, THOMAZINI APBW AND THOMAZINI MJ 2003. Insetos. In: RAMBALDI DM AND OLIVEIRA DAS (Eds), Fragmentação de ecossistemas: causas, efeitos sobre a biodiversidade e recomendações de políticas públicas. Brasília: Ministério de Meio Ambiente, Brasil, p. 240-273.

AtTAdemo AM, Peltzer PM AND LajManovich RC. 2005. Amphibians occurring in soybean and implications for biological control in Argentina. Agr Ecosyst Environ 106: 389-394.

BARBAULT R. 1991. Ecological constraints and community dynamics linking community patterns to organismal ecology. The case of herpetofaunas. Acta Oecol 12: 139-163.

BENCKE GA. 2009. Diversidade e conservação da fauna dos Campos do Sul do Brasil. In: PILLAR VP ET AL. (Eds), Campos Sulinos, conservação e uso sustentável da biodiversidade. Brasília: Ministério de Meio Ambiente, Brasil, p. 101-121.

BERNARDE PS. 2007. Ambientes e temporada de vocalização da anurofauna no Município de Espigão do Oeste, Rondônia, Sudoeste da Amazônia - Brasil (Amphibia: Anura). Biota Neotrop 17: 87-92.

BOLDRINI II. 2009. A flora dos campos do Rio Grande do Sul. In: PILLAR VPET AL. (Eds), Campos Sulinos, conservação e uso sustentável da biodiversidade. Brasília: Ministério de Meio Ambiente, Brasil, p. 63-77.

Both C, Kaefer IL, SANTos TG and Cechin SZ. 2008 An austral anuran assemblage in the Neotropics: seasonal occurrence correlated with photoperiod. J Nat Hist 42: 205222.

Both CS, Melo AS, Cechin SZ AND Hartz SM. 2011 Tadpole co-occurrence in ponds: When do guilds and time matter? Acta Oecol 37: 140-145.

BRANDÃO T, TREVISAN R AND BOTH R. 2007. Unidades de Conservação e os campos do Rio Grande do Sul. Rev Bras Bioci 5: 843-845.

CANAVERO A AND ARIM M. 2009. Clues supporting photoperiod as the main determinant of seasonal variation in amphibian activity. J Nat Hist 1: 2975-2984.

Canavero A, Arim M And Brazeiro A. 2009. Geographic variations of seasonality and coexistence in communities: The role of diversity and climate. Austral Ecol 34: 741-750.

Canelas MAS AND Bertoluci J. 2007. Anurans of the Serra do Caraça, southeastern Brazil: species composition and phenological patterns of calling activity. Iheringia, Sér Zool 97: 21-26.

CECHIN SZ AND MARTINS M. 2000. Eficiência de armadilhas de queda (pitfall traps) em amostragens de anfíbios e répteis no Brasil. Rev Bras Zool 17: 729-740.

CEI JM. 1980. Amphibians of Argentina. Ital J Zool 2: 1-609.

ClARK KR AND GORLEY RN. 2006. Software PRIMER v6. PRIMER-E, Plymouth, $192 \mathrm{p}$.

CLARK KR AND WARWICK RM. 2001. Change in marine communities: an approach to statistical analysis and interpretation. $2^{\text {nd }}$ ed., Primer-E, Plymouth, $172 \mathrm{p}$.

CONNEL JH. 1978. Diversity in Tropical Rain Forests and Coral Reefs. Science, New Series 199: 1302-1310.
CORDEIRO JLP AND HASENACK H. 2009. Cobertura vegetal atual do Rio Grande do Sul. In: PILLAR VP ET AL. (Eds), Campos Sulinos - conservação e uso sustentável da biodiversidade. Brasília: Ministério de Meio Ambiente, Brasil, p. 285-299.

DUFRÊNE M AND LEGENDRE P. 1997. Species assemblages and indicator species: the need for a flexible asymmetrical approach. Ecol Monogr 67: 345-366.

GotTSBERGER B AND GRUBER E. 2004. Temporal partitioning of reproductive activity in a neotropical anuran community. J Trop Ecol 20: 271-280.

HEYER WE. 1978. Systematics of the fuscus group of the frog genus Leptodactylus (Amphibia, Leptodactylidae). Nat Hist Mus 29: 1-85.

IBGE - InSTITUTO BRASILEIRo DE GEOGRAFIA E EstatístiCA. 2004. Mapa de Biomas do Brasil - Primeira aproximação. Brasília: Ministério do Meio Ambiente, Brasil.

INGER RF AND COLWELL RK. 1977. Organization of contiguous communities of amphibians and reptiles in Thailand. Ecol Monogr 47: 229-253.

Julião GR, Amaral MEC, Fernandes GW AND OliveIRA EG. 2004. Edge effect and species-area relationships in the gall-forming insect fauna of natural forest patches in the Brazilian Pantanal. Biodivers Conserv 13: 2055-2066.

KRISHNAMURTHY SV. 2003. Amphibian assemblages in undisturbed and disturbed areas of Kudremukh National Park, Central Western Ghats, India. Environ Conserv 30: 272-282.

LILLYWHite HB, LICHT P AND CHELGREN P. 1973. The role of behavioral thermoregulation in the growth energetic of the toad, Bufo boreas. Ecology 54: 375-383.

Lima AP, MAgNUSSON WE AND WiLliams DG. 2000. Differences in diet among frogs and lizards coexisting in subtropical forest of Australia. J Herpetol 34: 40-46.

LOEBMANN D AND VIEIRA JP. 2005. Relação dos anfíbios do Parque Nacional da Lagoa do Peixe, Rio Grande do Sul, Brasil. Rev Bras Zool 22: 339-341.

LUCAS EM AND FORTES VB. 2008. Frog diversity in the Floresta Nacional de Chapecó, Atlantic Forest of southern Brazil. Biota Neotrop 8: 51-61.

MALUF JRT. 2000. Nova classificação climática do Estado do Rio Grande do Sul. Rev Bras Agromet 8: 141-150.

MAnZANo AS, BALdo D AND BARG M. 2004. Anfibios del Litoral Fluvial Argentino. INSUGEO. Miscelánea 12: 271-290.

MoReIRA LFB, MACHAdo IBF, LACE ARGM AND MALTCHIK L. 2007. Calling period and reproductive modes in an anuran community of a temporary pond in southern Brazil. S Am J Herpetol 2: 129-135.

MoREIRA LFB, MACHADO IF, GARCIA TV AND MALTCHIK L. 2010. Factors influencing anuran distribution in coastal dune wetlands in southern Brazil. J Nat Hist 44: 14931507.

MoReIRA LFB AND MALTChIK L. 2012. Assessing patterns of nestedness and co-occurrence in coastal pond anuran assemblages. Amphibia-Reptilia 33: 261-271. 
NúÑEZ D, MANEyro R, LANGONE J AND SÁ RO. 2004. Distribución geográfica de la fauna de anfibios del Uruguay. Smith Herpetol Inform Serv 140, 34 p.

OBSERVATÓRIO NACIONAL. 2012. Online database. Disponível em: http://www.euler.on.br.

OLIVEIRA-FILHO AT, JARENKOW JÁ AND RODAL MJN. 2006. Floristic relationships of seasonally dry forests of Eastern South America based on tree species distribution patterns. In: PENNINGTON RT ET AL. (Eds), Neotropical savannas and dry forests: plant diversity, biogeography and conservation. Boca Raton: CRC Press, p. 151-184.

PARIS KM. 2004 Environmental and spatial variables influence the composition of frog assemblages in sub-tropical eastern Australia. Ecography 27: 392-400.

PARIS KM AND MCCARTHY MA. 1999. What influences the structure of frogs assemblages at forest streams? Aust J Ecol 24: 495-502.

Peltzer PM, Lajmanovich RC, Attademo AM AND Beltzer AH. 2006. Diversity of anurans across agricultural ponds in Argentina. Biodivers Conserv 15: 3499-3513.

Peltzer PM, Lajmanovich RC AND Beltzer AH. 2003. The effects of habitat fragmentation on amphibian species richness in the floodplain of the middle Parana river, Argentina. Herpetol J 13: 95-98.

Pereira PRB, NetTo LRG, Borin CJA AND SARTori MGB. 1989. Contribuição à geografia física do município de Santa Maria: unidades de paisagem. Geog: Ens Pesq 3: 37-68.

Pineda E AND Halffter G. 2004. Species diversity and habitat fragmentation: frogs in a tropical montane landscape in Mexico. Biol Conserv 117: 499-508.

Prado CA, Uetanabaro M ANd Haddad CFB. 2005. Breeding activity patterns, reproductive modes, and habitat use by anurans (Amphibia) in a seasonal environment in the Pantanal, Brazil. Amphibia-Reptilia 26: 211-221.

RIES L, FLETCHER JR RJ, BATTIN J AND SISK TD. 2004. Ecological responses to habitat edges: mechanisms, models, and variability explained. Ann Rev Ecol Evol Sys 35: 491-522.

SANChez LC, Peltzer PM AND MANZANo AS. 2007. Dinámica de un ensamble de anuros en un humedal del tramo inferior del río Paraná, Argentina. INCI 32: 463-470.

Santos TG, Kopp K, Spies MR, TRevisan R And Cechin SZ. 2008: Distribuição temporal e espacial de anuros em área de Pampa, Santa Maria, RS. Iheringia, Sér Zool 98: 244-253.

SANTOS TG AND TREVISAN R. 2009. Eucaliptos versus Bioma Pampa: compreendendo as diferenças entre lavouras de arbóreas e o campo nativo. In: TEIXEIRA-FILHO A (Ed), Lavouras de Destruição: a (im)posição do consenso. Pelotas, RS: produção independente, Brasil, p. 299-332.

SCHLAEPFER MA AND GAVIN TA. 2001. Edges effects on lizards and frogs in Tropical forests fragments. Conserv Biol 15: 1079-1090.

SILVA FR, CANDEIRA CP AND RoSSA-FERES DC. 2012. Dependence of anuran diversity on environmental descriptors in farmland ponds. Biodivers Conserv 21: 1411-1424.
SILVA FR AND RoSSA-FerES DC. 2007. Uso de fragmentos florestais por anuros (Amphibia) de área aberta na região noroeste do Estado de São Paulo. Biota Neotrop 7: 141-148.

SILVA FR AND RosSA-FERES DC. 2011. Influence of terrestrial habitat isolation on the diversity and temporal distribution of anurans in an agricultural landscape. J Trop Ecol 27: 327-331.

Silvano DL, Coli GR, DiXo MBO, Pimenta BVS AND WIEDERHECKER HC. 2003. Répteis e anfíbios. In: RAMBALDI DM AND OLIVEIRA DAS (Eds), Fragmentação de Ecossistemas: Causas, efeitos sobre a biodiversidade e recomendações de políticas públicas. Brasília: Ministério de Meio Ambiente, Brasil, p. 184-238.

ToFT CA. 1985. Resource partitioning in amphibians and reptiles. Copeia 5: 1-21.

TOMÉ MTC, ZAMUdiO KR, GIOVANELli JGR, HADDAD CFB, BALDISSERA JR FA AND ALEXANDRINO J. 2010. Phylogeography of endemic toads and post-Pliocene persistence of the Brazilian Atlantic Forest. Mol Phylogenetic Evol 55: 1028-1031.

URBINA-CARDONA JN, OLIVARES-PÉREZ M AND REYNOSO VH. 2006. Herpetofauna diversity and microenvironment correlates across a pasture-edge-interior ecotone in tropical rainforest fragments in the Los Tuxtlas Biosphere Reserve of Veracruz, Mexico. Biol Conserv 132: 61-75.

VAn Sluys M, VRcibradic D, Alves MAS, Bergallo HG AND ROCHA CFD. 2007. Ecological parameters of the leaf-litter frog community of an Atlantic Rainforest area at Ilha Grande, Rio de Janeiro state, Brazil. Austral Ecol 32: $254-260$.

VASCONCELOS TS AND ROSSA-FERES DC. 2005. Diversidade, distribuição espacial e temporal de anfíbios anuros (Amphibia, Anura) na região noroeste do Estado de São Paulo, Brasil. Biota Neotrop 5: 1-14.

VASCONCELOS TS, SANTOS TG, ROSSA-FERES DC AND HADDAD CFB. 2009. Influence of the environmental heterogeneity of breeding ponds on anuran assemblages from southeastern Brazil. Can J Zool 87: 699-707.

VAsconcelos TS, SANTOS TCG, Rossa-Feres DC AND HADDAD CFB. 2010. Similarity of ground-dwelling anuran (Amphibia) composition among different vegetation physiognomies in a Mesophytic Semideciduous Forest from southeastern Brazil. Northwest J Zool 6: 275-285.

Wellborn GA, SKelly DK AND WERNER EE. 1996. Mechanisms creating community structure across a freshwater habitat gradient. Ann Rev Ecol Sys 27: 337-363.

Wente WH AND PHILLIPS JB. 2005. Microhabitat selection by the Pacific treefrog, Hyla regilla. Anim Behav 70: 279-287.

WiLlians SE AND Hero JM. 2001. Multiple determinants of Australian tropical frog biodiversity. Biol Conserv 98: 1-10.

ZARANChO VH, CÉSPedeZ JÁ AND Álvarez BB. 2004. Caracterización de las puestas de especies del género Physalaemus (Anura: Leptodactylidae) en Argentina. Bol Asoc Herpetol Esp 15: 100-104. 